\title{
SNRPF wt Allele
}

National Cancer Institute

\section{Source}

National Cancer Institute. SNRPF wt Allele. NCI Thesaurus. Code C52056.

Human SNRPF wild-type allele is located within 12q23.1 and is approximately $7 \mathrm{~kb}$ in length. This allele, which encodes small nuclear ribonucleoprotein $\mathrm{F}$ protein, is involved in spliceosome-mediated nuclear mRNA splicing. 